PRACE KomisJi GeOGRAFII PRZEMYSLU PTG

NR 3

WARSZAWA-KRAKÓW-RZESZÓW 2001

\author{
MAGDALENA WDOWICKA
}

\title{
Wykształcanie się nowych obszarów przemysłowych w strefie podmiejskiej Poznania
}

Przemiany systemu społeczno-gospodarczego Polski wywarły zasadniczy wpływ na tempo i charakter procesów urbanizacji. Największym przeobrażeniom uległy centra miast, obszary przemysłowe, układy komunikacyjne oraz peryferie. Warto zauważyć, że transformacja ta dokonuje się w warunkach postępującej globalizacji procesów produkcji, integracji rynków i gospodarek, malejącej roli granic państwowych dla przepływu międzynarodowych kapitałów oraz rosnącej międzynarodowej konkurencji. Sytuacja ta niewątpliwie stwarza nowe uwarunkowania rozwoju aglomeracji miejskich.

Proces adaptacji miast do nowych uwarunkowań gospodarki światowej zależy przede wszystkim od stopnia zróżnicowania ich struktury społeczno-gospodarczej. Taką koncepcję prezentują B. Jałowiecki (1993), J. Parysek (1995) i T. Markowski (1999). Najlepiej radzą sobie miasta o wysoce zróżnicowanej strukturze gospodarczej, których działalność przemysłowa nigdy nie zdominowała innych rodzajów aktywności, jak również miasta pełniące funkcje centrów usługowych, administracyjnych, finansowych, handlowych i kulturalnych, posiadające dobrze rozwinięte uczelnie wyższe i nawiązane już od lat międzynarodowe kontakty gospodarcze. Przykładami mogą być: Londyn, Paryż, Mediolan, Praga, a w Polsce: Warszawa, Poznań, Kraków i Wrocław.

Jednym z najistotniejszych egzogenicznych czynników mogących przyczynić się do zdynamizowania rozwoju gospodarczego, zarówno w skali regionalnej jak i lokalnej - na poziomie miast i gmin - jest napływ zagranicznego kapitału inwestycyjnego. Wiąże się on $\mathrm{z}$ transferem nowoczesnych technologii produkcji i technik zarządzania. Inwestycje zagraniczne stwarzają również popyt na siłę roboczą, a zatem mogą przyczyniać się do spadku bezrobocia. Pośrednio z kolei oddziałują na poprawę jakości produkcji, jej elastyczność i specjalizację, innowacyjność techniczną wzrost wydajności pracy, podnoszenie kwalifikacji miejscowej ludności, ukształtowanie nowoczesnego kierownictwa, upowszechnianie postaw przedsiębiorczości, podnoszenie sprawności funkcjonowania samorządów terytorialnych, a także na wzrost dochodów ludności. Lokalizowanie nowych inwestycji ma również zasadniczy wpływ na przekształcenia przestrzenno-funkcjonalne miast i obszarów podmiejskich oraz kształtowanie nowego ładu przestrzennego (Tab.1.).

Napływ obcego kapitału w formie inwestycji bezpośrednich staje się zjawiskiem coraz bardziej znaczącym w polskiej gospodarce. Przedsiębiorcy zagraniczni, zainteresowani ulokowaniem kapitału w Polsce, miejsce lokalizacji swoich inwestycji wiążą głównie z dużymi, znanymi ośrodkami miejsko - przemysłowymi, łatwiej przez nich dostrzeganymi i identyfikowanymi. Od 1990 roku, zgodnie z szacunkami Europejskiego Banku Odbudowy i Rozwoju, ich wartość osiagnęła kwotę około 12 mld USD, z czego 1,5 mld USD przypada na województwo poznańskie (w granicach sprzed 1999 roku). Należy jednak stwierdzić, iż 
większość z tych inwestycji skoncentrowana jest w samym Poznaniu (ponad 1 miliard USD) oraz gminach bezpośrednio $\mathrm{z}$ nim sąsiadujących (tab.2, ryc.1). Jak wykazały badania przeprowadzone przez gdański Instytut Badań nad Gospodarką Rynkową, Poznań jest obecnie drugim w kraju, po Warszawie, miastem o najwyższej atrakcyjności inwestycyjnej.

Tab.1. Czynniki determinujące decyzje lokalizacyjne inwestorów.

\begin{tabular}{|c|c|}
\hline Niezależne od władz samorządowych & Zależne od władz samorządowych \\
\hline $\begin{array}{ll}- & \text { położenie geograficzne } \\
- & \text { środowisko przyrodnicze } \\
- & \text { śodowisko tworzone przez } \\
& \text { makroekonomiczną politykę } \\
& \text { państwa } \\
- & \text { poziom inflacji } \\
\text { - } & \text { obraz kraju za granicą }\end{array}$ & $\begin{array}{ll}\text { - } & \text { klimat sprzyjający przedsiębiorczości } \\
\text { - } & \text { jasne, precyzyjne przepisy i prawa gminne oraz ich } \\
& \text { stabilność } \\
\text { - } & \text { promocja obszarów, zachęcająca do inwestowania na } \\
& \text { terenie gminy } \\
\text { - } & \text { dobrze rozwinięta infrastruktura techniczna } \\
- & \text { korzystny system podatków lokalnych } \\
- & \text { polityka zmierzająca do udostępnienia inwestorom } \\
& \text { gruntów } \\
\text { - } & \text { jakość obsługi w urzędzie }\end{array}$ \\
\hline
\end{tabular}

Źródło: opracowanie własne

Tab.2. Nakłady inwestycyjne w gminach strefy podmiejskiej Poznania w latach 1990-1995 na 1 mieszkańca.

\begin{tabular}{|l|c|c|c|c|c|c|}
\hline \multirow{2}{*}{ Gminy } & \multicolumn{5}{|c|}{ Nakłady inwestycyjne na 1 mieszkańca w tys. zł. } \\
\cline { 2 - 7 } & $1990 \mathrm{r}$. & $1991 \mathrm{r}$. & $1992 \mathrm{r}$. & $1993 \mathrm{r}$. & $1994 \mathrm{r}$. & $1995 \mathrm{r}$. \\
\hline Luboń & 0,13 & 0,31 & 0,26 & 0,14 & 0,24 & 0,37 \\
\hline Puszczykowo & 0,10 & 0,16 & 0,08 & 0,16 & 0,50 & 0,38 \\
\hline Kórnik & 0,09 & 0,18 & 0,18 & 0,23 & 1.88 & 0,11 \\
\hline Mosina & 0,22 & 0,15 & 0,19 & 0,19 & 0,29 & 0,37 \\
\hline Swarzędz & 0,57 & 0,73 & 0,88 & 0,67 & 0,81 & 0,68 \\
\hline Czerwonak & 1,00 & 1,19 & 1,52 & 0,85 & 0,86 & 0,72 \\
\hline Dopiewo & 0,27 & 0,14 & 0,15 & 0,17 & 0,35 & 0,25 \\
\hline Kleszczewo & 0,21 & 0,27 & 0,27 & 0,46 & 0,53 & 0,09 \\
\hline Komorniki & 0,08 & 0,10 & 0,19 & 0,46 & 0,44 & 0,37 \\
\hline Rokietnica & 0,06 & 0,10 & 0,04 & 0,16 & 0,11 & 0,11 \\
\hline Suchy Las & 0,40 & 0,24 & 0,29 & $0,42 \cdot$ & 0,84 & 0,74 \\
\hline Tarnowo Podgórne & 0,09 & 0,28 & 0,28 & 1,98 & 2,04 & 2,57 \\
\hline
\end{tabular}

Źródło: Obliczenia własne na podstawie opracowania Wydziału Rozwoju Regionalnego Urzędu Wojewódzkiego w Poznaniu. 


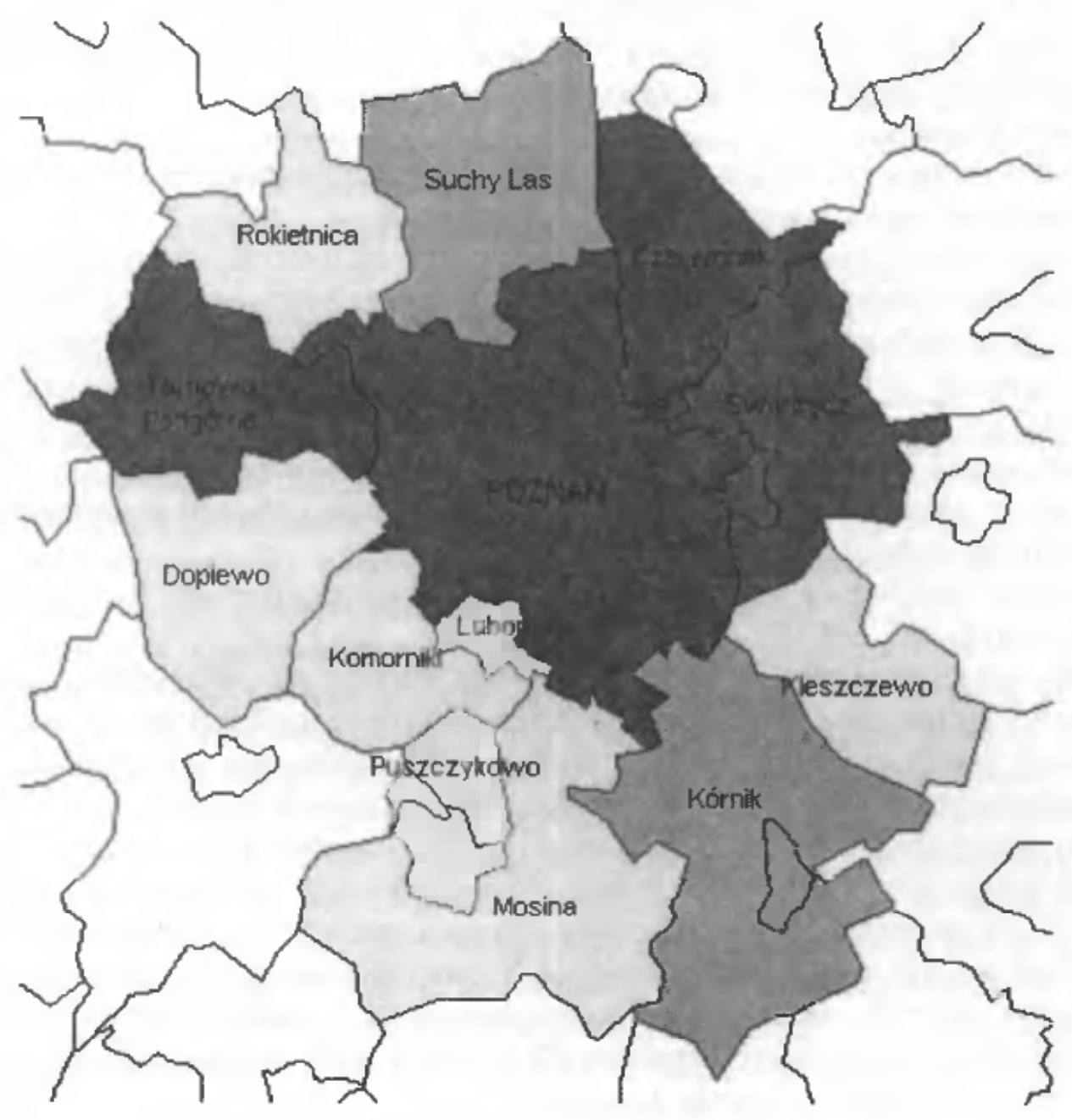

poniżej $2000 \mathrm{zl}$. 2001-4000 zl.

$4001-6000 \mathrm{zl}$.

powyżej $6000 \mathrm{zl}$.

Ryc.1. Wartośc inwestycji w latach 1990-1995 na 1 mieszkańca w gminach aglomeracji poznańskiej

Źródło: Opracowanie własne na podstawie danych Wydziału Rozwoju Regionalnego Urzędu Wojewódzkiego w Poznaniu

$\mathrm{Na}$ atrakcyjność inwestycyjną danego obszaru składa się kilkadziesiąt różnych cech i czynników, z których pojedynczy inwestor uwzględnia kilka lub co najwyżej kilkanaście. Obecnie za najistotniejsze czynniki lokalizacji inwestycji uznaje się:

1) dostępność przestrzenną miejsc określoną między innymi przez położenie w stosunku do głównych dróg krajowych i międzynarodowych, linii kolejowych, lotnisk, planowanych autostrad, przejść granicznych, a także bliskość dużych ośrodków miejskich, 
2) rynek pracy, zwłaszcza dostępność wykwalifikowanej kadry (naukowców, inżynierów, menedżerów), ale również niska cena pracy niewykwalifikowanej oraz słaba aktywność związków zawodowych,

3) ceny gruntów,

4) infrastrukturę techniczną, w tym przede wszystkim uzbrojenie terenu w sieć kanalizacyjną, wodociągową, gazową i telefoniczną,

5) Środowisko dla biznesu, czyli obecność instytucji tworzących sprzyjające środowisko dla działalności gospodarczej (tzw. business environment), tj. banków, instytucji pośrednictwa kapitałowego, instytucji doradczych i ubezpieczeniowych, ośrodków i instytutów naukowo-badawczych, agencji rozwoju regionalnego i lokalnego, ośrodków innowacji i przedsiębiorczości itp.,

6) aktywność marketingową i przychylność władz samorządowych,

7) ogólny poziom rozwoju społeczno-gospodarczego i stopień zaawansowania oraz kierunki transformacji gospodarki,

8) jakość środowiska przyrodniczego i społecznego (por. P. Swaniewicz, 1997, B. Jałowiecki, 1993).

Aglomeracja poznańska, na tle miast polskich, cechuje się szczególnie dużą dynamiką rozwoju społeczno-gospodarczego. Niezwykle silnym czynnikiem jej aktywizacji i konkurencyjności inwestycyjnej w stosunku do innych obszarów, jest jej usytuowanie na obszarze pomostowym miedzy zachodem a wschodem Europy (w połowie drogi z Berlina do Warszawy). Przez obszar ten przechodzi najważniejszy korytarz transportowy z Unii Europejskiej do krajów Centralnej i Wschodniej Europy, łączący główne europejskie regiony miejskie. Warto zauważyć, iż dynamicznym tempem przekształceń charakteryzuje się nie tylko sam Poznań, ale jego obszar podmiejski, szczególnie ten, który leży w rejonie wspomnianych największych ciążeń społeczno-gospodarczych, a zatem gminy: Tarnowo Podgórne i Swarzędz. Dodatkowym impulsem dla rozwoju gmin podpoznańskich jest budowa autostrady A-2 oraz bliskość lotniska Lawica.

Aglomeracja poznańska wykazała dużą podatność na transformację oraz zdolności adaptacyjne w zakresie innowacji technologicznych i organizacyjnych (J. Parysek, 1996). Zasadniczą rolę odegrał tu potencjał społeczny, gospodarczy i naukowy Poznania. Poznań postrzegany jest jako ośrodek wielofunkcyjny o zróżnicowanej strukturze przemysłu, w której obok dużych przedsiębiorstw, istniało sporo drobnych i średnich firm, łatwo przystosowujących się do nowych warunków gospodarczych, co umożliwiło sprawne zrealizowanie procesu prywatyzacji i szybkie wyjście z recesji. Stopniowo w aglomeracji poznańskiej wykształca się nowa struktura gospodarcza, w której coraz większą rolę odgrywa sektor III i IV tj. szeroko rozumiane usługi. Zmiany w strukturze przemysłu dotyczą przede wszystkim zmniejszenia roli jego tradycyjnych „cięższych” gałęzi i branż na rzecz gałęzi o zaawansowanej technice. Został uruchomiony proces prywatyzacji i rozwoju indywidualnej przedsiębiorczości. W 1997 roku ponad $98 \%$ ogólnej liczby podmiotów gospodarczych zarejestrowanych w systemie Regon, na obszarze strefy podmiejskiej, stanowiły firmy prywatne. Dynamicznie rozwija się, właściwy dla gospodarki rynkowej, sektor otoczenia biznesu, który tworzy sprzyjające środowisko dla działalności inwestycyjnej. Zasadniczą rolę odgrywają tu usługi rynkowe, świadczone przez różnorodne instytucje finansowe i ubezpieczeniowe $\mathrm{w}$ zakresie elastycznego systemu kredytowania, udzielania pożyczek gwarancyjnych, dotacji, wchodzenia kapitału w często ryzykowne przedsięwzięcia. 
Współczesne przekształcenia przestrzeni miejskiej dokonują się w wyniku dwóch zasadniczych procesów. $\mathrm{Z}$ jednej strony mamy do czynienia $\mathrm{z}$ procesem dezindustrializacji, polegającym na likwidacji przestrzeni przemysłowych w mieście i zastępowaniu ich innymi rodzajami działalności, $\mathrm{z}$ drugiej natomiast strony - z procesem industrializacji, wiążącym się z powstawaniem nowych przestrzeni produkcji poza obszarem miejskim.

Dezindustrializację poprzez likwidację przedsiębiorstw obserwuje się w szczególności w regionach dawnego uprzemysłowienia i w tradycyjnych branżach. W aspekcie przestrzennym oznacza ona porzucenie zajmowanych dotychczas terenów i budynków, które często pozostają długo nie zagospodarowane, tworząc tzw. odłogi przemysłowe (Jałowiecki, 1993). zasadniczym problemem staje się rewitalizacja tych obszarów. Działania takie zostały już z powodzeniem podjęte $\mathrm{m}$. in. w Zagłębiu Ruhry (gdzie na obszarach poprzemysłowych wprowadzono funkcje kulturalne i usługowo-handlowe), w Amsterdamie i Rotterdamie (gdzie przekształcono stare tereny portowe adoptując je m.in. pod socjalne budownictwo mieszkaniowe). Podobne rozwiązania możnaby zastosować w Polsce. Propozycje zagospodarowania terenów poprzemysłowych posiada już przykładowo Ruda Śląska (dla 140 ha obszarów poprzemysłowych po kopalni „Wawel” i koksowni „Walenty”). Planuje się tutaj stworzenie nowoczesnej dzielnicy przemysłowo-usługowej, w skład której wejdą strefy przemysłu zaawansowanego technologicznie, małych zakładów produkcyjnych, centrów przedsiębiorczości, usług logistycznych oraz handlu, a także terenów zielonych.

Z kolei proces wykształcania się nowych obszarów przemysłowych na obrzeżach miast wyraźnie widoczny jest na terenie aglomeracji poznańskiej i zaczyna odgrywać coraz bardziej znaczącą rolę w przekształcaniu jej struktury przestrzennej. W wyniku oddziaływania "sił wypychających" z centrum miasta obserwuje się relokację funkcji przemysłowych i magazynowo-składowych do strefy podmiejskiej oraz zastępowanie ich użytkowaniem usługowym, a w niektórych przypadkach - uźytkowaniem mieszkaniowym (Gaczek, 1992). W związku z tym Poznań (jako ośrodek o funkcjach metropolitalnych) staje się miejscem koncentracji najbardziej wyspecjalizowanych funkcji kierowniczych i innych działalności blisko z nimi związanych, takich jak: usługi finansowe, bankowe i ubezpieczeniowe, doradztwo podatkowe, prawne, usługi marketingowe oraz działalności badawczorozwojowych. Z kolei na obszarze podmiejskim lokalizują się nowoczesne przemysły.

Na proces powstawania nowych przestrzeni produkcji w strefie podmiejskiej Poznania ma ponadto wpływ zwiększająca się konkurencyjność gmin podpoznańskich w stosunku do obszaru miasta. Do czynników podnoszących ich atrakcyjność inwestycyjną można zaliczyć: (1) zdecydowanie niższe ceny gruntów niż w Poznaniu, niższe czynsze i podatki, (2) tańszą siłę roboczą, (3) dostępność wolnych terenów do zagospodarowania, (4) sąsiedztwo obszarów zainwestowanych (które wpływa na wzajemne przyciąganie się kolejnych inwestycji), (5) przyjemne środowisko mieszkaniowe (Grzeszczak, 1998). Na niekorzyść Poznania wpływa poza tym: (1) pogarszająca się infrastruktura miejska, (2) zatory w ruchu drogowym i problemy z dostępnością, (3) ograniczenia stwarzane przez planowanie miejskie, (4) wyczerpywanie się wolnych terenów budowlanych.

Napływające coraz liczniej inwestycje zagraniczne, związane z produkcją, nie znajdują miejsca na działalność w granicach Poznania. Inwestorzy zainteresowani są nabywaniem działek o dużych powierzchniach użytkowych, odpowiednich do rozwoju poziomych technologii produkcji i umożliwiających ekspansję in situ, a takich na terenie miasta bra- 
kuje. W związku z powyższym przedsiębiorstwa przemysłowe, inwestowane od podstaw i wymagające rozleglejszych terenów budowlanych, lokalizują się poza granicami miasta.

Położenie gmin w orbicie gospodarczego oddziaływania Poznania dodatkowo zwiększa ich atrakcyjność lokalizacyjną. Atuty wynikające z bliskości dużej metropolii to przede wszystkim większa chłonność rynku zbytu, wysokiej jakości rynek pracy, bliska odległość do centrów decyzyjnych, dostęp do dynamicznie rozwijającego się sektora otoczenia biznesu, a także tzw. milieu miasta (sfery kultury i nauki), wpływające na jakość życia. Atutem jest zatem lokalizowanie inwestycji przemysłowych w bezpośrednim sąsiedztwie Poznania, jednak nie w samym Poznaniu.

Poważną rolę w kształtowaniu konkurencyjności warunków lokalizacji przemysłu odgrywa podnoszenie atrakcyjności inwestycyjnej gmin przez władze samorządowe. Istnieje wysoka świadomość, iż przyciągnięcie zewnętrznego kapitału inwestycyjnego jest jednym z ważniejszych i efektywnych sposobów dynamizujących gospodarkę układu lokalnego. Specyficzne efekty przestrzenne powoduje działalność inwestycyjna podmiotów zagranicznych. Dysponując odpowiednimi nakładami kapitałowymi są bowiem w stanie podejmować znaczne inwestycje i kończyć je w krótkich terminach. Są także w stanie nabywać droższe tereny budowlane, zbyt kosztowne dla inwestorów krajowych. Niezwykle atrakcyjne dla władz lokalnych są zwłaszcza przemysły zaawansowanej techniki i technologii, ponieważ są to przemysły czyste, wykazujące znaczną dynamikę wzrostu i mają charakter prestiżowy. Gmin pragnących przyciągnąć inwestycje jest jednak znacznie więcej niż chętnych inwestorów. Fakt ten wywołuje konkurencję między gminami i miastami. W celu zachęcania inwestorów zagranicznych do lokalizowania przedsiębiorstw na terenie gminy stosuje się wiele działań (tab.1.). Niektóre gminy, w tym podpoznańskie Tarnowo Podgórne, z przyciągania inwestorów uczyniły główną oś swojej skutecznej strategii rozwoju. Jednym z najważniejszych czynników lokalizacji przemysłu, uzależnionym w bardzo dużym stopniu od władz samorządowych jest przygotowanie odpowiednich stref przeznaczonych pod aktywizację gospodarczą oraz przeprowadzenie inwestycji z zakresu infrastruktury technicznej. Pozwala to na udostępnienie inwestorom, pod działalność gospodarczą, terenów uzbrojonych w sieć kanalizacyjną, wodociągową i gazową. Szczególne znaczenie ma również uporządkowanie stosunków własnościowych, przeprowadzenie podziałów geodezyjnych i scalanie gruntów. Kluczową rolę odgrywa prowadzenie przez władze lokalne działalności marketingowej, promującej możliwości inwestowania w gminie (poprzez wydawanie folderów, uczestniczenie w targach inwestycyjnych). Przy czym chodzi tutaj o profesjonalnie przygotowaną, kompleksową informację o regionie, nie tylko eksponującą mocne strony gminy, ale również wskazującą na istniejące problemy z jednoczesną propozycją możliwości ich rozwiązania (Rząd, 1999). Istotna jest też rola administracji samorządowej w ułatwianiu procedur administracyjnych.

Ważnym czynnikiem staje się przyciąganie nowych inwestycji przez już istniejące. Zgrupowane $w$ jednym miejscu wielu przedsiębiorstw ułatwia przepływ informacji i powoduje efekt synergii. Zjawisko to można wyraźnie zaobserwować we wspomnianej już wcześniej gminie Tarnowo Podgórne, gdzie pierwsze lokalizacje inwestycji niemieckich stworzyły pozytywne impulsy dla następnych inwestorów - również niemieckich.

Wykształcanie się nowych obszarów przemysłowych w strefie podmiejskiej Poznania wiąże się z sukcesją funkcji poszczególnych terenów. Najczęściej nowe przestrzenie produkcji powstają na obszarach, które były dotychczas użytkowane rolniczo, bądź na tere- 
nach magazynowo-składowych i zazwyczaj wiążą się z inwestycjami podmiotów zagranicznych. Ekspansja terenów zainwestowanych przebiega w różnych kierunkach strefy peryferyjnej. Koncentracja nowych przedsiębiorstw przemysłowych następuje zwłaszcza wzdłuż głównych dróg wylotowych z Poznania. Dotyczy to w szczególności gmin: Tarnowo Podgórne, Swarzędz, Komorniki, Suchy Las i Czerwonak. Największą konkurencyjnością warunków lokalizacji przemysłu charakteryzuje się gmina Tarnowo Podgórne, w której łączna wartość inwestycji prowadzonych przez firmy z udziałem kapitału zagranicznego wynosi około $270 \mathrm{mln}$ USD, co wyróżnia tę gminę na mapie gmin inwestorów, także w skali kraju (tab.2). Nowe zakłady produkcyjne lokalizowane są przede wszystkim w rejonie międzynarodowej trasy Berlin-Warszawa-Moskwa. Swoją działalność zlokalizowały tutaj tak renomowane koncerny jak: Stollwerck - producent czekolady, Elite Coffee producent kawy, MAN - producent autobusów, Reemstma - Wytwórnia Wyrobów Tytoniowych, Stühl - producent sprzętu do prac leśnych i ogrodowych, Hammer - producent opakowań, Sulzer - producent wkładów do wież destylacyjnych i wiele innych.

Duże zainteresowanie wśród inwestorów budzą również gminy: Czerwonak (gdzie swoją działalność zlokalizował m.in. Neoplan - producent autobusów oraz Hawle - producent armatury), Komorniki (HBZ Meble - producent mebli, Hörmann - producent bram garażowych i przemysłowych), Suchy Las (Pepsi Cola General Bottlers - producent napojów), Swarzędz (Vox Industrie - producent mebli), Kórnik (firmy logistyczne: Raben oraz Kühne \& Nagel). Analiza przestrzennego rozkładu inwestycji na terenie strefy podmiejskiej Poznania, wskazuje na szczególne zainteresowanie inwestorów lokalizacją przedsiębiorstw wzdłuź przebiegu budowanej autostrady A-2. Na inwestycjach tych prawdopodobnie najwięcej skorzystają gminy: Komorniki, Dopiewo i Kleszczewo.

Kapitał zagraniczny ukierunkowany jest przede wszystkim na uruchamianie i budowanie zakładów przemysłowych od podstaw, na tzw. zielonym polu (greenfield investments). Pod względem wielkości zatrudnienia dominują firmy duże, zatrudniające powyżej 100 osób (ponad 60\%). Znaczną część stanowią przedsiębiorstwa zatrudniające 200 i więcej pracowników (ponad $30 \%$ ). Stosunkowo niski udział mają zakłady zatrudniające poniżej 50 osób (25\%).

Głównymi kierunkami inwestowania kapitału zagranicznego jest przemysł spożywczy (Elite Coffee, Stollwerck, Pepsi Cola General Bottlers), tytoniowy (Reemstma), meblowy (HBZ Meble, Vox Industrie), moloryzacyjny (Neoplan, MAN), ceramiczny i metalowy (Marmite International, Hawle) oraz działalność spedycyjna (Kühne \& Nagel, Raben). Rynkami zbytu dla większości lokalizowanych zakładów produkcyjnych są kraje Europy Środkowej i Wschodniej. Analizując strukturę inwestycji według kraju pochodzenia, można stwierdzić, iż najwięcej kapitału zainwestowali w gminach podpoznańskich Niemcy, co jest zrozumiałe z racji geograficznego położenia aglomeracji poznańskiej. Pozostały kapitał pochodzi z Holandii, Austrii, Szwajcarii, Szwecji, USA i Włoch.

Reasumując warto skonfrontować rzeczywisty napływ zagranicznego kapitału inwestycyjnego do strefy podmiejskiej Poznania z oceną konkurencyjności warunków lokalizacyjnych poszczególnych gmin przez inwestorów ${ }^{1}$.

\footnotetext{
' Badania ankietowe przeprowadzone wśród inwestorów na obszarze strefy podmiejskiej Poznania w 1998 r., dotyczące oceny atrakcyjności inwestycyjnej gmin podpoznańskich.
} 
Opinie inwestorów potwierdziły najwyższą atrakcyjnosć inwestycyjną gminy Tarnowo Podgórne - spośród wszystkich gmin poddanych analizie. Na kolejnych miejscach wedhug ocen inwestorów plasują się gminy: Komorniki i Suchy Las. Obecność istotnych, w procesie inwestycyjnym, czynników przedsiębiorcy odnajdują również w gminach: Swarzędz, Czerwonak i Kórnik.

O wysokiej atrakcyjności inwestycyjnej wymienionych gmin zdaniem inwestorów zadecydowały przede wszystkim:

- dobra dostępność przestrzenna (lokalizacja przy międzynarodowej drodze Berlin Warszawa - Moskwa lub drodze Praga - Wrocław - Gdańsk, lokalizacja w pobliżu lotniska, stosunkowo nieduża odległość od granicy w Świecku, bliskość dużego ośrodka miejskiego - Poznania)

- szeroka oferta wolnych terenów do zagospodarowania, uzbrojonych w infrastrukturę techniczną

- sprzyjający inwestowaniu stosunek do kapitału zagranicznego władz samorządowych i społeczności lokalnej.

Najmniejszą - jak się okazuje - szansę pozyskania inwestorów posiadają gminy o charakterze typowo rolniczym i stosunkowo niskim poziomie rozwoju gospodarczego, takie jak Kleszczewo czy Rokietnica.

\section{Literatura}

Dąbrowski J. (red.)1996. Mapa ryzyka inwestycyjnego. Instytut Badań nad Gospodarką Rynkową.

Gaczek W.M. 1992. Proces zmian użytkowania terenów w rejonie miejskim na przykladzie Poznania. Zeszyty AE, ser.II,117,Poznań.

Grzeszczak J. 1998.Przesunięcie miasto-wieś w przemyśle krajów Unii Europejskiej. Zeszyty IGiPZ PAN, nr 55, Warszawa.

Jałowiecki B. 1993. Polityka restrukturyzacji regionów - doświadczenia europejskie. Studia Regionalne i Lokalne 11 (44), UW, EIRRiL, Warszawa.

Markowski T. 1999. Zarządzanie rozwojem miast. PWN, Warszawa.

Parysek J.J. 1995. Duże miasta Europy $i$ ich rola $w$ procesie urbanizacji, rozwoju spoleczno-gospodarczym i europejskiej integracji u schylku XX wieku. Przegląd Geograficzny, T. LXVII, z. 3-4.

Parysek J.J. 1996. Poznań i aglomeracja poznańska. Proces transformacji spolecznogospodarczej $i$ perspektywy dalszego rozwoju. [w:] Aglomeracje miejskie w procesie transformacji: II. Korcelli P. (red.), Zeszyty IGiPZ PAN, nr 42, Warszawa.

Rząd E. 1999. Jak cię promować regionie? [w:] Pomorski przegląd gospodarczy. Nr 1, IBnGR, Gdańsk.

Swaniewicz P. 1997. Przyciaganie inwestycji jako element samorzqdowej polityki rozwoju ekonomicznego. Samorząd Terytorialny, nr 12, s. 3-11, Warszawa. 